\title{
Lysosomal activation by neutral saccharides in cell cultures of synovium
}

\author{
JENNIFER LE MARSHALL, J. R. E. FRASER, AND K. D. MUIRDEN
}

From the University of Melbourne Department of Medicine, Royal Melbourne Hospital, Victoria 3050, Australi $\vec{P}$

SUMMARY On exposure to sucrose or neutral polysaccharides, cell cultures from human synovium showed cytoplasmic vacuolation, increased numbers of lysosomes, and ultrastructural changes simulating those described in rheumatoid synovial intima and similarly treated embryonic cartilage and bone. These changes were accompanied by raised intracellular lysosomal enzyme activity without corresponding increases in the extracellular level of these enzymes. Structural changes and enzymien responses were less intense during exposure to the neutral polysaccharides. The secretion of large? polymers of hyaluronic acid was consistently decreased during sucrose treatment. Evidence of heightened hyaluronidase-like activity was found in cellular extracts of sucrose-treated cultures, but not in the culture medium.

Increased activity of the lysosomal system is a prominent feature of arthritis. It can be seen in the ultrastructure of synovial intima and in the enzyme content of synovial tissue extracts and synovial fluid. There is an increased extracellular release of lysosomal enzymes from whole synovial tissue excised from joints treated with chitin or diazo dyes (Page Thomas, 1969), and a strong association has been observed between synovial lysosomal enzyme activity and the damage to cartilage and bone seen at synovectomy (Muirden, 1972).

The part played by synovium in the degradation of cartilage matrix in arthritis may depend upon neutral proteases as much as upon acid hydrolases from lysosomes (Dingle, 1975), but there are other aspects of the function of both normal and inflamed joints in which the synovial lysosomes may be concerned. These include the catabolism of hyaluronic acid, which unlike the proteoglycans contains very little covalently linked protein and is not directly degraded by proteases. Yet hyaluronic acid or its breakdown products can escape rapidly from the joint space into synovial intima, cartilage, lymph node, and blood stream (Antonas et al., 1973), which suggests that the synovial intima might help to cause breakdown as well as synthesis of hyaluronic acid. Slight hyaluronidase activity has been reported in human fluid and synovial tissue (Bollet et al., 1963) from autopsy material.

The controlled activation of the lysosomal system was therefore studied in cultured cells of synovial

Accepted for publication July 22, 1976

Correspondence to Dr. J. R. E. Fraser origin, using sucrose in a manner similar to that used in cartilage and other cell cultures (Dingle $e t$ al. 1969; Nyberg and Dingle, 1970). The polysacs charides, dextran and Ficoll, were used for com parison. Since preliminary studies indicated thap synovial cells might not release their lysosomaP enzymes so readily with comparable stimulation $\overrightarrow{\overrightarrow{0}}$ (Le Marshall et al., 1973), their reactions were studied in more detail.

\section{Materials and methods}

\section{CELL CULTURE}

Lines of synovial cells were derived from non rheumatoid tissues as described earlier (Fraser ans, McCall, 1965), and from rheumatoid synoviumo obtained by synovectomy, in which the intima was gently separated and dispersed with trypsin for the primary culture. Observations were made in the diploid phase of serial culture (Clarris and Fraseros 1968). Five replicate cultures were allotted to each treatment group to permit statistical assessmentu within each experiment. Experimental media con ${ }_{\sigma}^{\omega}$ tained $10-25 \% \mathrm{v} / \mathrm{v}$ heat-inactivated serum in medium 199 which provides a relatively slow growth rate in control cultures (see Clarris and Fraser, 1967) Growth rates were calculated as the percentage increase in cell numbers per day, and the mean celb numbers for the duration of each experimenta treatment were used for comparison of enzyme activities and secretory rates in terms of equivalene cell numbers. Biochemical measurements were made between 4 and 8 days in culture. 


\section{SACCHARIDES}

Dextrans (Dextrans 10, 80, 150, 500; MW 10-500 × $10^{3}$; Pharmacia) and the sucrose polymer, Ficoll (Pharmacia), were thoroughly dialysed and freezedried. Sucrose was of analytical grade (British Drug Houses). The saccharides were dissolved in medium 199 and sterilized by membrane filtration $(0.22 \mu \mathrm{m}$ pore-size). Final concentration of sucrose was $0.08 \mathrm{~mol} / \mathrm{l}$. The polysaccharides were used in the equivalent $\mathrm{w} / \mathrm{v}$ concentration of $2 \cdot 8 \mathrm{~g} / 100 \mathrm{ml}$.

\section{PHASE-CONTRAST MICROSCOPY}

Negative-medium phase contrast illumination was used.

\section{SUPRAVITAL STAINING}

The cultures were washed in balanced salt solution, exposed in darkness to acridine orange (G. T. Gurr; 22657) for $15-20$ minutes at $37^{\circ} \mathrm{C}$, washed, and examined as wet preparations.

\section{ELECTRON MICROSCOPY}

The cells were washed with phosphate-buffered saline and fixed in situ with $2 \%$ glutaraldehyde in cacodylate buffer, $\mathrm{pH} 7.4$ at $4^{\circ} \mathrm{C}$ for at least 4 hours. The cell layer was detached with a Teflon scraper, spun into pellets, washed in buffered sucrose solution, and treated with $2 \%$ osmium tetroxide for 30 minutes. The pellets were dehydrated and stained with uranyl acetate and lead acetate.

\section{HISTOCHEMISTRY OF ACID PHOSPHATASE}

The methods of Goldberg and Barka (1962), Barka and Anderson (1962), and Pearse (1968) were adapted for use in polystyrene culture flasks. Rinsing buffer and fixative contained $0.25 \mathrm{~mol} / 1$ sucrose. Substrate was $\alpha$-naphthylphosphate (Gurr 21524), with fast garnet GBC (Gurr 23203) as coupling dye, and Mayer's haemalum or methyl green as counterstain. Appropriate control preparations showed no specific staining. Differences in morphology and specific staining were assessed in paired control and treated cultures presented to the observer in random order.

\section{DIRECT MEASUREMENT OF ENZYMES \\ Preparation of samples}

Culture media were centrifuged at $10000 \mathrm{~g}$ for 10 minutes for measurement of enzyme in the supernatant. Centrifuged cell pellets were rapidly prepared from measured aliquots of the saline-trypsin suspensions used for cell counts. The pellets were frozen and thawed, dispersed in $3.5 \mathrm{ml}$ of $0.25 \mathrm{~mol} / 1$ sucrose, pH 7.0 in $0.01 \mathrm{~mol} / 1$ TRIS buffer, briefly exposed to an ultrasonic field, and centrifuged at $600 \mathrm{~g}$ for 15 minutes.

\section{$N$-acetyl- $\beta$-D-glucosaminidase}

The incubation mixture contained $0.5 \mathrm{ml} 0.1 \mathrm{~mol} / 1$ citrate buffer, $\mathrm{pH} 4.5 ; 0.5 \mathrm{ml} 0.2 \%$ Triton $\mathrm{X}-100$ (Packard Instrument Co.); $0.5 \mathrm{ml}$ substrate (3.6 mmol/l p-nitrophenyl phosphate-2-acetamido-2deoxy- $\beta$-D-glycopyranose); and $0.5 \mathrm{ml}$ test sample (culture medium or cell extract). Test samples were incubated at $37^{\circ} \mathrm{C}$ for $1-2$ hours, and the reaction was stopped by $4 \mathrm{ml}$ of $1.0 \mathrm{~mol} / 1$ borate buffer, pH 9.8. Appropriate standards, and reagent and culture medium controls were included.

\section{$\beta$-glucuronidase}

The incubation mixture contained $0.1 \mathrm{ml} 0.1 \mathrm{~mol} / 1$ acetate buffer, $\mathrm{pH} 4.5 ; 0.1 \mathrm{ml} 0.1 \%$ Triton X-100; $0.1 \mathrm{ml}$ substrate $(1.5 \mathrm{mmol} / 1$ phenolphthalein glucuronide, sodium salt); and $0.1 \mathrm{ml}$ test sample (culture medium or cell extract). Incubation was continued at $37^{\circ} \mathrm{C}$ for 15 hours, and the reaction stopped by $0.4 \mathrm{ml}$ of $0.2 \mathrm{~mol} / 1$ glycine buffer, $\mathrm{pH}$ 10.4. Controls were as above.

\section{Hyaluronidase}

Observations were made with cell extracts only. (i) Viscometry. Highly polymerized hyaluronic acid with a low protein content was used (Fraser et al., 1972). $1 \mathrm{ml}$ of cell extract was mixed with $0.5 \mathrm{ml}$ $0.1 \mathrm{~mol} / 1$ citrate buffer, $\mathrm{pH} 4.5$, and $0.5 \mathrm{ml}$ of $0.2 \%$ Triton X-100 with merthiolate as an antiseptic, and the mixture warmed to $37^{\circ} \mathrm{C} .1 \mathrm{ml}$ of hyaluronic acid solution was added, carefully mixed, and the solution immediately transferred to the viscometer. Extracts from control and treated cultures were studied concurrently in matched calibrated viscometers. (ii) $\mathrm{N}$-acetylhexosamine assay. The method of Reissig et al. (1955) was used.

\section{Dextranase}

The same viscometric procedure was used with Dextran $150,5 \% \mathrm{w} / \mathrm{v}$ in phosphate-citrate buffer, pH 5.0, as substrate.

\section{STUDIES OF HYALURONIC ACID \\ Isotopic methods}

Incorporation of ${ }^{14} \mathrm{C}$-glucose $(3.3 \mu \mathrm{Ci} / \mathrm{ml})$ in culture media and the further analysis followed methods described earlier (Baxter et al., 1973). Dried precipitates were taken up in $0.5 \mathrm{ml}$ of formic acid $(90 \%)$, dried again, and dissolved in $0.5 \mathrm{ml}$ of Hyamine (Packard Instrument Co.), or dissolved direct in Hyamine, and added to a toluene-based scintillation fluid.

Quaternary ammonium $\left(\mathrm{QN}^{+}\right)$precipitation (Harris and Fraser, 1969)

False estimates of hexuronic acid residues of neutral 
saccharides were avoided by washing the cetyltrimethylammonium precipitate twice with $20 \mathrm{ml}$ of distilled water. Recovery of hyaluronic acid in a concentration of $4 \mu \mathrm{g} / \mathrm{ml}$ of culture medium containing saccharides was $93 \%$.

\section{Gel chromatography}

Sephadex G200 (Pharmacia) was used as described previously (Baxter et al., 1973). The small-pore crosslinked polyacrylamide gel, Biogel P2 (BioRad Inc.), with a nominated exclusion point of 2600 daltons, was used to separate the smaller cell products. Other relevant details are given with the results.

\section{Results}

\section{CELL GROWTH}

Growth rates in control cultures were independent of (1) the duration, $x$, of observation between 3 and 10 days $(\mathrm{r}=0.017, \mathrm{n}=50 ; \mathrm{NS}) ;(2)$ the initial cell numbers, $y(\mathrm{r}=0.085, \mathrm{n}=50 ; \mathrm{NS}) ;$ and (3) interaction between these variables $\left(r_{x y}=0.25\right.$; NS).

Sucrose usually caused a significant but slight retardation of growth whereas the dextrans accelerated it. However, the growth-stimulating effect of dextran was inversely related to its molecular weight $(P<0.01)$. None of the changes was related to growth rate in matched control cultures $(r=-0 \cdot 17$ for sucrose; $r=0$ for dextran). After removal of the test media, sucrose-treated cultures recovered normal growth rates, whereas dextran-treated cultures continued to grow more rapidly for as long as $\mathbf{1 0}$ days. Rheumatoid cells tended to grow more slowly in control medium but did not show grossly different responses to sucrose or dextran (Table 1). Ficoll induced significant stimulation of growth in some experiments, and retardation in others. The differences in growth response to the several saccharides were confirmed by concurrent observation within individual experiments.

Table 1 Growth rates of rheumatoid and nonrheumatoid synovial cell strains in $20 \%$ serum

\begin{tabular}{|c|c|c|}
\hline & $\begin{array}{l}\text { Nonrheumatoid } \\
\text { cells } \\
(\text { mean } \pm S E)\end{array}$ & $\begin{array}{l}\text { Rheumatoid } \\
\text { cells } \\
(\text { mean } \pm S E)\end{array}$ \\
\hline $\begin{array}{l}\text { All observations } \\
\text { Growth rates* in } \\
\text { control medium } \\
\text { Groups treated with } \\
\text { (a) Sucrose }\end{array}$ & $18 \cdot 1 \pm 2 \cdot 3(n=24)$ & $14 \cdot 4 \pm 3 \cdot 1(n=10)$ \\
\hline $\begin{array}{l}\text { Growth rates in } \\
\text { control medium sucrose } \\
\text { (b) Dextrans }\end{array}$ & $\begin{array}{l}19 \cdot 1 \pm 3 \cdot 1(n=15) \\
16 \cdot 2 \pm 3 \cdot 2\end{array}$ & $\begin{array}{l}10.6 \pm 1.8(n=8) \\
9 \cdot 1 \pm 1 \cdot 8\end{array}$ \\
\hline $\begin{array}{l}\text { Growth rates in } \\
\text { control medium dextran }\end{array}$ & $\begin{array}{l}18 \cdot 3 \pm 2 \cdot 6(n=19) \\
25 \cdot 0 \pm 3 \cdot 0\end{array}$ & $\begin{array}{l}16 \cdot 0 \pm 3 \cdot 0(n=9) \\
19 \cdot 2 \pm 2 \cdot 9\end{array}$ \\
\hline
\end{tabular}

*Percentage increase in cell numbers per day.

\section{MOR P HOLOGY}

Phase-contrast microscopy

Control cultures showed some small refractil| organelles in all cells, and clear vacuoles in a fewo Sucrose-treated cells showed more numerous an widespread organelles, and many more vacuoles (Fig. 1). These differences were grossly developed b $\$$ 72 hours, when the treated cells were often larger ang globular. Other changes included increased opacity of the nuclear membrane and nucleus, crescentshaped clear vacuoles almost surrounding the nucleus, and structureless bodies next to and nearle as large as the nucleus, which were considered to bo hypertrophied Golgi bodies. In dextran there was an increase in fine organelles and small vacuoles, but fewer large vacuoles and less distortion of cell shape than in sucrose. Ficoll-treated cultures presentees changes intermediate between those caused bg sucrose and dextran. These changes persisted after change to control medium. The intensity of respons was not related to growth rates. No evidence of celt necrosis or increase in cell debris was observed in the saccharide-treated cultures.

\section{Supravital staining}

Differential staining was obtained with $5 \mu \mathrm{g}$ acridine orange per $\mathrm{ml}$. The cytoplasm of untreated cells wa lightly scattered with fine distinct organelles whiclo were mainly central and fluoresced a bright red in

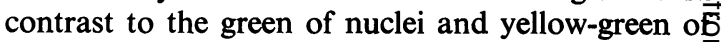
nucleoli. These were presumed to be lysosomes? Their numbers were similar in rheumatoid and non rheumatoid cells, and in both were grossly increased. by saccharide treatment, especially with sucrose in which the cytoplasmic staining was less stable during exposure to light (Fig. 2). In 5 experiments performed with 2 rheumatoid and 3 nonrheumatoid cell-linesi all saccharide-treated groups ( 5 sucrose, 5 dextran and 3 Ficoll) showed similar reactions.

\section{Electron microscopy}

In control cultures the cells were mostly spindle shaped with large elongated nuclei and multiples nucleoli. The cytoplasm contained many mito+v chondria and most cells showed abundant endoplastn mic reticulum and a well-developed Golgi apparatus (Fig. 3). In some areas the cisternae of the endoplasmic reticulum were dilated and contained pale granular material. Vacuoles of varying size (diameters? $0.3-0.8 \mu \mathrm{m}$ ), bounded by a single or double mem $=$ brane, contained granular material, small vesicleso ('multivesicular bodies') and infrequently myelin-D like forms. Dense bodies (lysosomes) were generally inconspicuous and small (diameter $0.5 \mu \mathrm{m}$ ). Only a few larger lysosomes $(1.0 \mu \mathrm{m})$ and autophagice vacuoles were seen. 
Sucrose-treated cells were swollen by an increased bulk of cytoplasm and were more rounded. The major changes were in increase in vacuoles and lysosomes relative to endoplasmic reticulum and Golgi apparatus (Fig. 4). The vacuoles (diameters $0.5-1.5 \mu \mathrm{m})$ contained granular material of varying electron density, including myelin-like forms, partly organized debris, such as degenerate mitochondria (autophagic vacuoles-Fig. 5) and smaller vesičles. Some of the larger vacuoles held unique rod-like structures with a rudimentary cross-banding and a fine horizontal lamination (Fig. 4). These structures

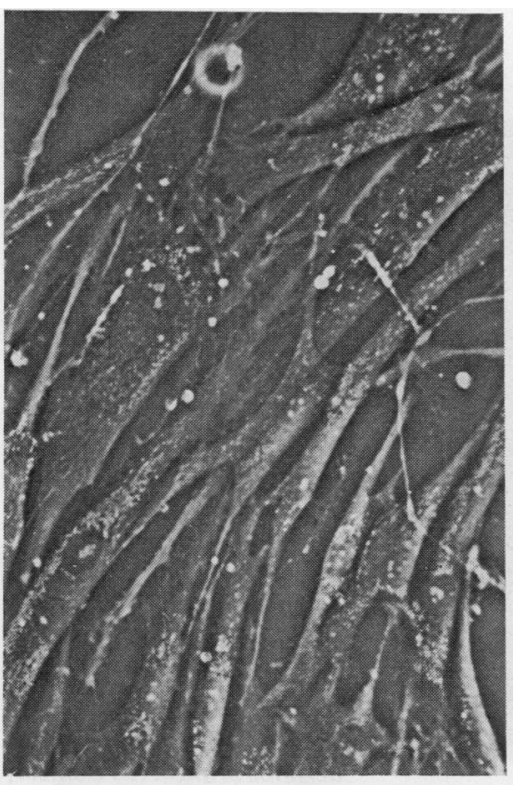

(a)

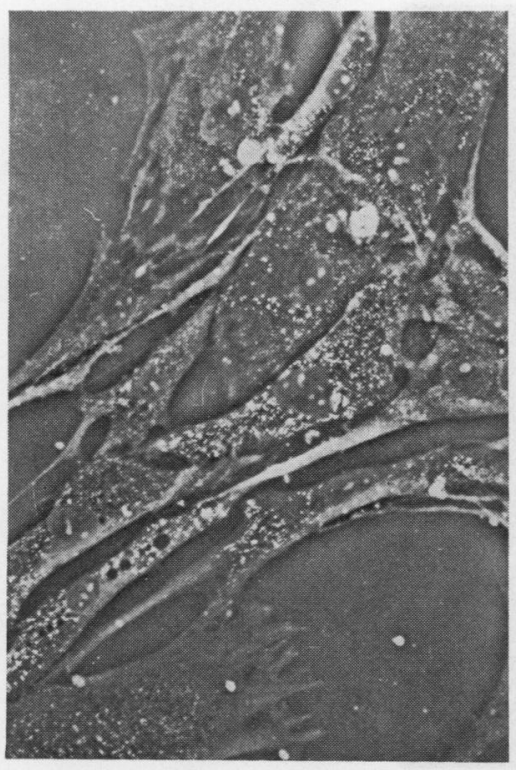

(c)

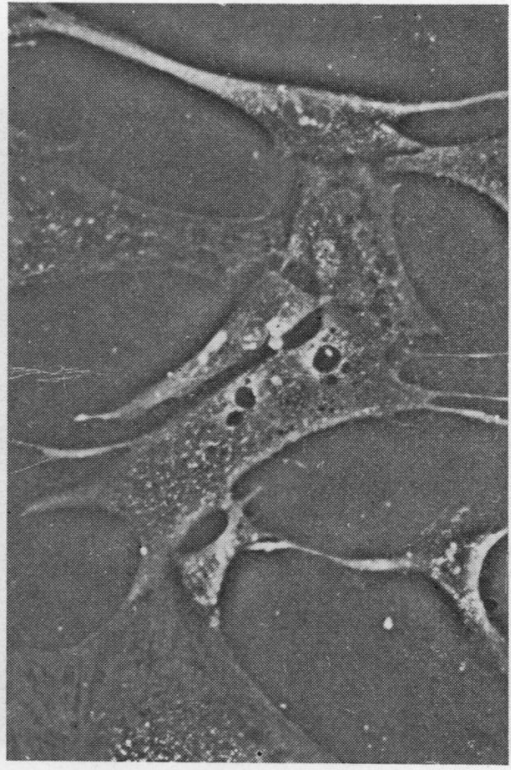

(b)

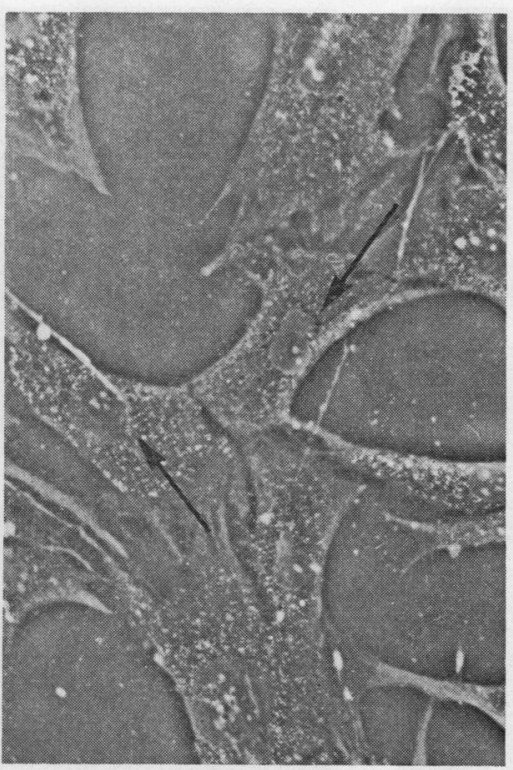

(d)
Fig. 1 Synovial cells. Negative medium phase-contrast. (a) Control culture. (b) Sucrose-treated culture: large vacuoles, (c) large cells, extensive refractile organelles, and small vacuoles, and $(d)$ example of amorphous juxtanuclear zones (arrows). $\times 420$. 
were not seen in control or Ficoll-treated cells. One section captured a process suggesting extrusion of a residual body (Fig. 5). Other features were increased numbers of fine cytoplasmic filaments, dilated endoplasmic reticulum, and swollen mitochondria. A small proportion of cells was identical with those of control cultures, and others showed cytoplasm with reduced organelles, a few scattered vesicles ribosomes, and mitochondria only. Cell debris and. intercellular background were similar to those? of control cultures.

Ficoll-treated cells showed changes intermediat between those of control and sucrose-treate $\Phi$ cultures. The cells showed well-developed endo\&

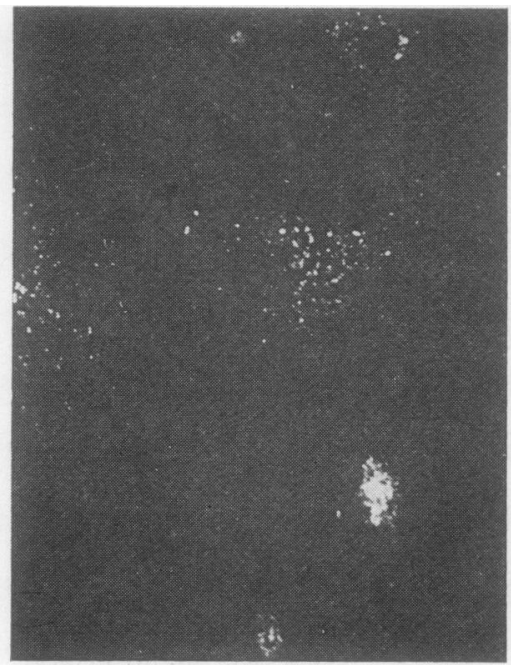

(a)

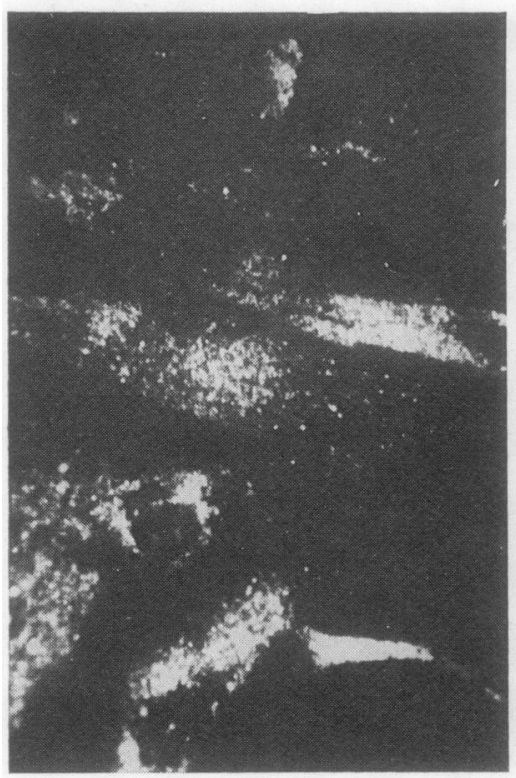

(c)

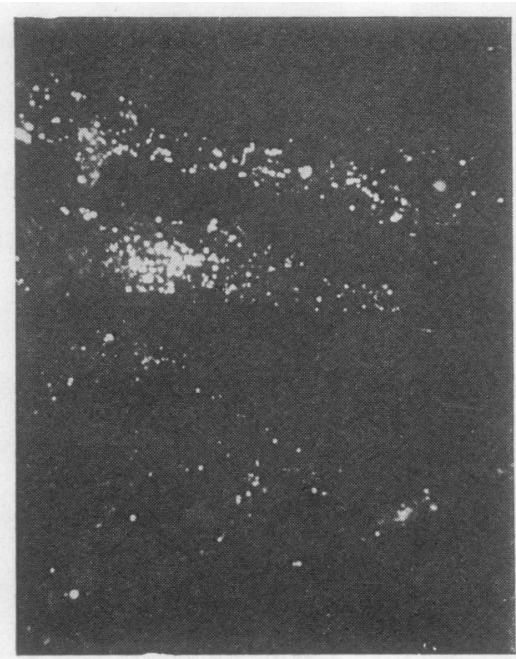

(b)

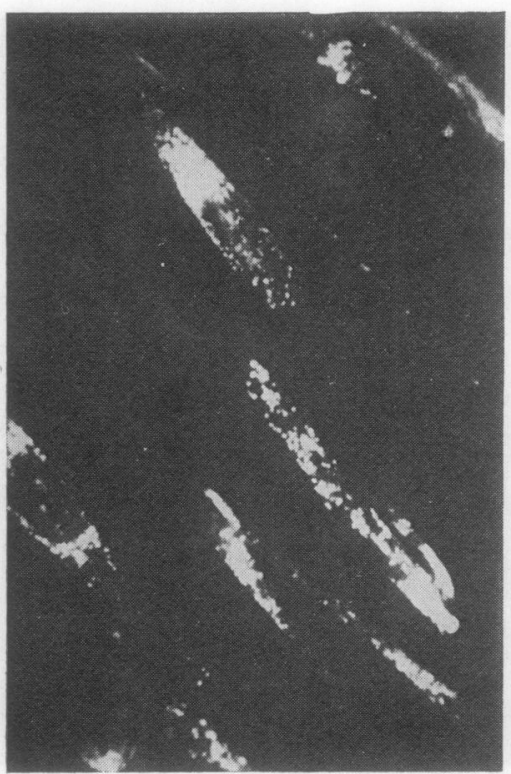

$(d)$
Fig. 2 Synovial culture. Supravital staining with acridine orange. (a) Control rheumatoid origin, (b) nonrheumatoid origin. (c) Nonrheumatoid, sucrose-treated, $(d)$ Ficoll-treated. Lysosomes most extensive in (c) but showing loss of definition during exposure. $\times 615$. 
plasmic reticulum and a Golgi apparatus, but also increased numbers of vacuoles and lysosomes including autophagic vacuoles.

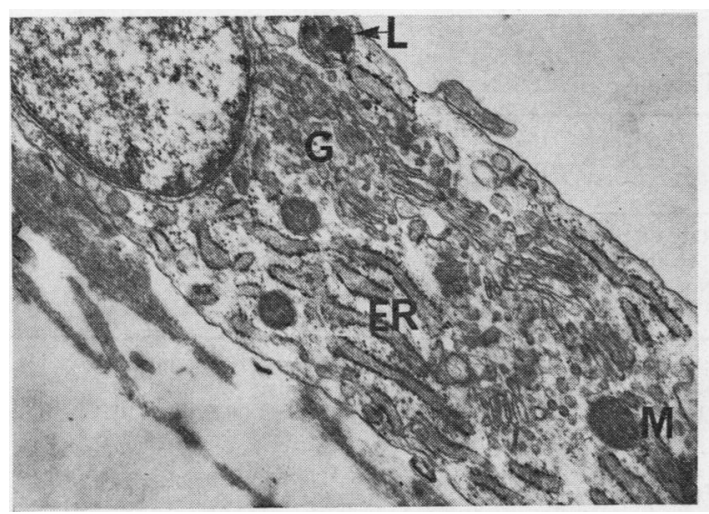

Fig. 3 Synovial cells, control culture. Note welldeveloped Golgi apparatus $(G)$; lysosomal body $(L)$; endoplasmic reticulum $(E R)$; and small mitochondria $(M)$. $\times 8350$.

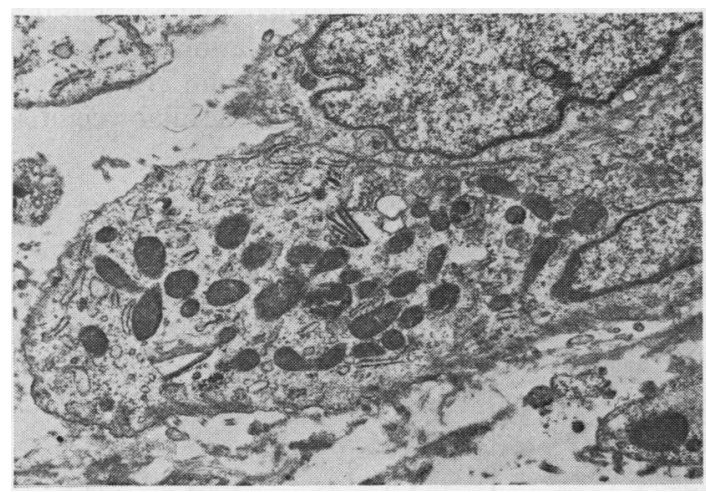

Fig. 4 Synovial cells, sucrose-treated culture. There are increased numbers of vacuoles and lysosomal bodies relative to Golgi apparatus and endoplasmic reticulum. $\times 7150$.

\section{ENZYME STUDIES}

\section{Acid phosphatase}

All control and treated cultures showed specific staining, which was more extensive and in larger granules in the sucrose-treated cultures. Significant increase in staining was detected in all of 5 studies with sucrose, 6 of 8 with dextran, and 2 of 3 with Ficoll. Increased staining in polysaccharide-treated cultures was less intense than in sucrose-treated cultures.

\section{$N$-acetyl- $\beta$-D-glucosaminidase}

Total enzymic activity in control cultures ranged from 99 to 294 units. There was a negative correlation between total enzyme content and the proportion found in the extracellular fluid $(r=-0.65$; $P<0.05$ ). Responses to saccharides are summarized in Table 2. In all experiments sucrose caused a significant increase in intracellular and total activity, with a varied but consistent fall in the extracellular fraction (Wilcoxon $T=0 ; P<0.01$ ). Significant responses of the same pattern were found less frequently with dextran and Ficoll. The changes in

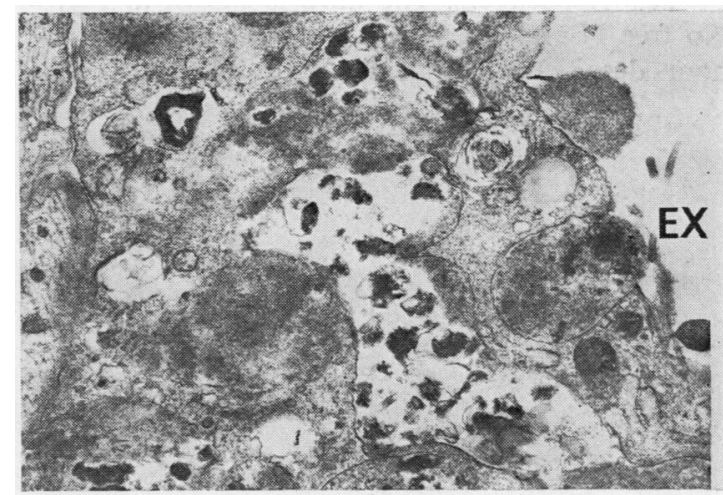

Fig. 5 Synovial cells, sucrose-treated culture. Cytoplasm shows large complex vacuoles containing cellular debris (autophagic vacuoles). Extrusion of residual body (EX). $\times 21500$

Table $2 \beta$-N-acetylglucosaminidase activity

\begin{tabular}{|c|c|c|c|c|c|c|}
\hline Treatment & No. of studies & Extracellular* & Intracellular* & Total* & Fraction excreted (\%) & Comment \\
\hline $\begin{array}{l}\text { Control } \\
\text { Sucrose }\end{array}$ & 9 & $\begin{array}{r}110 \\
74\end{array}$ & $\begin{array}{l}107 \\
343\end{array}$ & $\begin{array}{l}217 \\
417\end{array}$ & $\begin{array}{l}57 \\
24\end{array}$ & $\begin{array}{l}\text { Significant changes in } \\
\text { all studies }\end{array}$ \\
\hline $\begin{array}{l}\text { Control } \\
\text { Dextran }\end{array}$ & 6 & $\begin{array}{l}105 \\
101\end{array}$ & $\begin{array}{r}77 \\
129\end{array}$ & $\begin{array}{l}181 \\
230\end{array}$ & $\begin{array}{l}64 \\
50\end{array}$ & $\begin{array}{l}\text { Significant changes } \\
\text { in } 2 \text { studies }\end{array}$ \\
\hline $\begin{array}{l}\text { Control } \\
\text { Ficoll }\end{array}$ & 6 & $\begin{array}{l}106 \\
112\end{array}$ & $\begin{array}{r}78 \\
133\end{array}$ & $\begin{array}{l}133 \\
245\end{array}$ & $\begin{array}{l}64 \\
51\end{array}$ & $\begin{array}{l}\text { Significant changes } \\
\text { in } 3 \text { studies }\end{array}$ \\
\hline
\end{tabular}

r $\mathrm{g}$ p-nitrophenol released per hour per $10^{6}$ cells. Means for each series of experiments. 
enzyme activity with saccharide treatment showed no correlation with cell concentrations, changes in growth rate, or glucose consumption.

\section{$\beta$-glucuronidase (Table 3)}

Measurable activity was relatively much lower. Sucrose induced changes similar to those in Nacetyglucosaminidase, whereas the polysaccharides induced changes little different from the controls.

Table $3 \quad \beta$-glucuronidase activity

\begin{tabular}{lllll}
\hline Treatment & $\begin{array}{l}\text { Extra- } \\
\text { cellular* }\end{array}$ & $\begin{array}{l}\text { Intra- } \\
\text { cellular* }\end{array}$ & Total & $\begin{array}{l}\text { Fraction } \\
\text { excreted (\%) }\end{array}$ \\
\hline Control & 1.03 & 2.83 & 3.86 & 26.7 \\
Sucrose & 0.02 & 4.48 & 4.50 & 4.4 \\
Ficoll & 1.27 & 2.73 & 4.00 & 31.5 \\
Dextran & 1.45 & 2.75 & 4.20 & 29.0 \\
\hline
\end{tabular}

* $\mu \mathrm{g}$ phenolphthalein released per hour per $10^{6}$ cells.

\section{Hyaluronidase}

Viscosity-reducing activity was found in 2 of 3 experiments. In one, viscosity fell in 18 hours by 15 and $18 \%$ with control and sucrose-treated cell extracts respectively. The third is shown in Fig. 6. No free $\mathrm{N}$-acetylhexosamine was detected after 25 hours despite the reduction in viscosity.

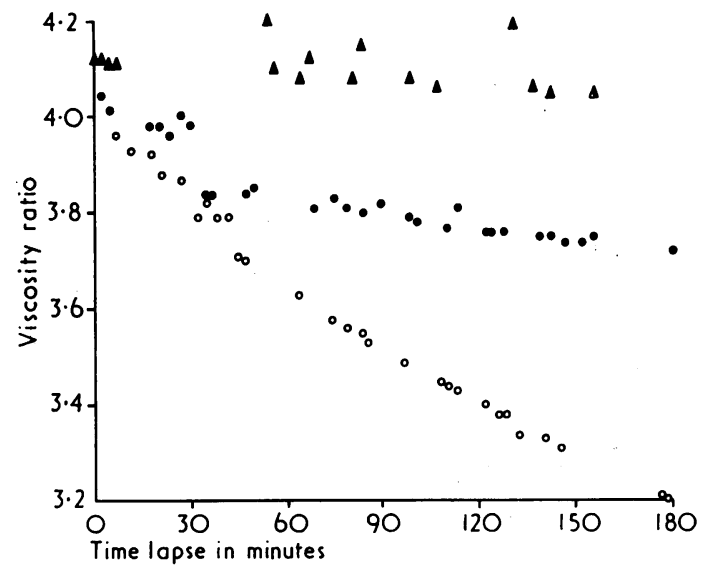

Fig. 6 Effects of cell extracts on hyaluronic acid. $\mathbf{\Delta}=$ reagents only $; \boldsymbol{\bullet}=$ cell extract from control culture; $\mathbf{0}=$ cell extract from sucrose-treated culture. Relative numbers of cells in extracts $\bullet$ and 0 were 1.12:1. Reduction in viscosity after 25 hours: $\triangle 6 \%, \bullet 21 \%$, o $49 \%$.

Dextranase

No activity was detected in 3 studies.
Hyaluronic acid metabolism

The rate of secretion (Table 4) was reduced in all experiments with sucrose, whereas in dextran and Ficoll secretory rates were reduced in 4 studies ondy and considerably increased in others.

Table 4 Secretion of hyaluronic acid

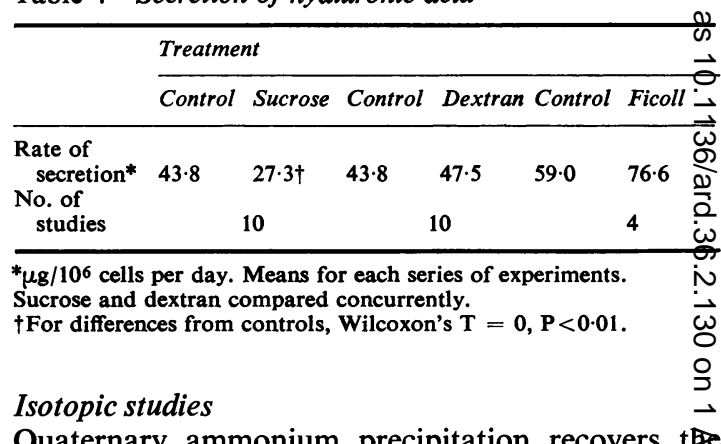

Quaternary ammonium precipitation recovers the larger polymers of hyaluronic acid (Scott, 1960), and in the present study gave similar estimates to those obtained by Sephadex G200 chromatography indicating a molecular weight of at least 200000 Culture media containing ${ }^{14} \mathrm{C}$-glucose were fraetionated in Biogel P2 (Fig. 7) where oligosaccharidês produced by hyaluronidase degradation were expe्दted to appear in several bands (Flodin et al., 196) between the first and third zones (molecular weight

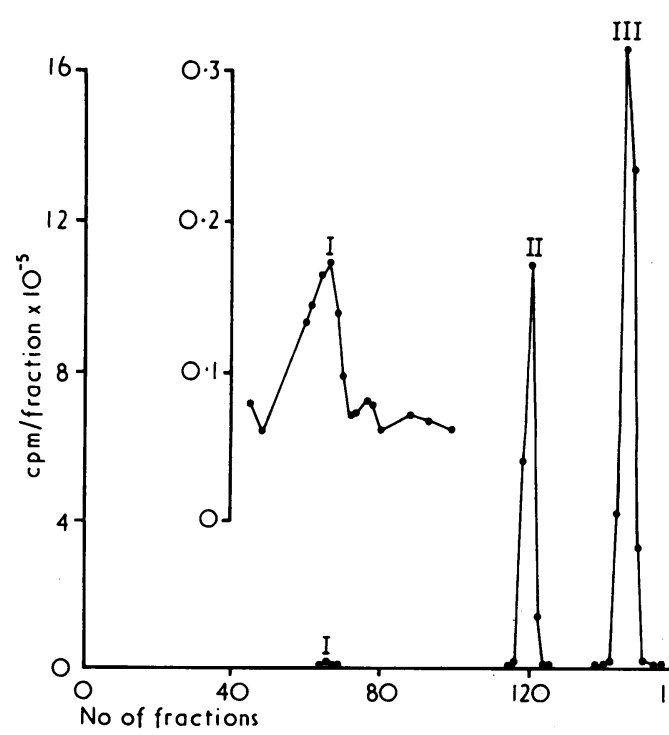

Fig. 7 Fractionation of control culture medium in Biogel P2. Gel bed $1.7 \times 100 \mathrm{~cm}$; eluant $0.15 \mathrm{~mol} / \mathrm{l}$ $\mathrm{NaCl}$; sample $1 \mathrm{ml}$, fractions $2 \mathrm{ml}$; flow rate $6 \mathrm{ml} / \mathrm{h}$. Inset: Zone I with expanded ordinate. 
2600 and $<300$ respectively). A single intermediate peak was found in both control and saccharidetreated cultures. This has since been shown to consist of lactic acid which has an anomalously small coefficient of distribution in Biogel P2 (E. Baxter and J. R. E. Fraser, unpublished). The isotopically labelled material recovered in the first fraction from Biogel columns was 2 to 4 times as abundant as that recovered by $\mathrm{QN}^{+}$precipitation, and was similar in amount to that precipitated by acid-ethanol with the method of Kochhar et al. (1968). In 3 studies the first fraction was slightly increased by sucrose and dextran treatment. Both treatments caused slight increases in glucose consumption and lactic acid excretion as measured by chromatographic fractionation.

\section{Discussion}

The morphological changes induced by the three saccharides were consistent for each, readily distinguished by phase contrast microscopy, and obvious with supravital staining and electron microscopy. Vacuolation was most prominent with sucrose as noted in hamster fibroblasts (Nyberg and Dingle, 1970). Proliferation of the fine organelles was also most intense in sucrose. Since these organelles have been identified with the lysosome system by their phase density (Munro et al., 1964) and by their specific fluorescence in acridine orange (Allison and Young, 1964, 1969; Dingle and Barrett, 1969), all the morphological evidence of lysosomal activation was most strongly developed in sucrose. Similar changes, though less intense, were also consistently induced by the polysaccharides, where changes in enzyme activity were less frequently detected. It is possible that the accelerated rates of cell growth commonly observed with the polysaccharides might have diverted cellular synthetic capacity from the lysosomal enzymes to a greater degree than from organelles, but this explanation was not supported by direct comparison of growth rates with enzyme activity. The electron microscope changes resembled those reported by Glauert et al. (1969) in sucrosetreated limb-bone rudiments; an increase in vacuoles with similar variety of content; greater cell bulk, and excellent preservation of the other cell organelles. The overall effect simulated the appearance of the abnormal type A cells of rheumatoid synovial intima.

The most striking finding was the failure of extracellular lysosomal enzyme activity to rise despite a threefold increase in intracellular enzyme. This contrasts with the effect of sucrose on embryonic limb bone rudiments (Dingle et al., 1969). Sucrose may stabilize the cytoplasmic membrane of the type of cell used in the present study. Alternatively, release of lysosomal enzymes from these cells may be actively controlled as in leucocytes and macrophages (Weissman et al., 1971) or may not occur in physiological conditions. It is notable that the ingestion of polystyrene latex particles by cultured rabbit synovial cells stimulates the release of collagenase and neutral proteases, with little increase in either the intracellular content or release of lysosomal enzymes (Werb and Reynolds, 1974). The enhanced release of lysosomal enzymes from synovium previously activated by lysosomal stimulants in vivo (Page Thomas, 1969) may reflect a modification of the cell membrane by the associated mild synovitis, sufficient to facilitate enzyme escape by passive exocytosis. In the normal joint it is difficult to see how the integrity of synovial fluid could be maintained in the face of controlled or random lysosomal enzyme release from the synovial membrane if its lysosomal enzymes include hyaluronidase. The capacity for the release of lysosomal enzymes, as distinct from neutral proteases, may be normally repressed in this kind of tissue.

Reduction of viscosity before liberation of measurable free $\mathrm{N}$-acetylhexosamine is consistent with the action of mammalian hyaluronidases (Meyer, 1947). Although intracellular hyaluronidase activity was not definitely proven by detection of free $\mathrm{N}$-acetylhexosamine, the observed reduction of viscosity by cell extracts, especially in those from sucrose-treated cultures, cannot be readily explained by any other agency. The lower recovery of the larger polymers of hyaluronic acid in sucrose-treated cultures could reflect an increased hyaluronidase activity, or might be an independent effect of other cellular changes induced by sucrose. There was an increase in the smaller secretory products similar to the increase in acid-ethanol precipitable material derived from glucosamine in mouse fibroblast cultures treated with retinol (Kochhar et al., 1968). However, the absence of polydisperse fractions in the fractionating range of Biogel P2 gel chromatography argues against any significant extracellular degradation of the secreted hyaluronic acid by a mammalian type of hyaluronidase, which should produce a series of oligosaccharides as noted above. The glucoselabelled material recovered by acid ethanol precipitation and in the void volume of Biogel P2 might include several glycoproteins (Baxter et al., 1973) as well as intermediate polymers of hyaluronic acid, and is the subject of current analysis.

This work was supported by a grant from the National Health and Medical Research Council of Australia. 


\section{References}

Allison, A. C., and Young, M. R. (1964). Uptake of dyes and drugs by living cells in culture. Life Sciences, 3, 1407-1414.

Allison, A. C., and Young, M. R. (1969). Vital staining and fluorescence microscopy of lysosomes. Lysosomes in Biology and Pathology, Vol. 22, p. 600 . Ed. by J. T. Dingle and H. B. Fell. North-Holland, Amsterdam.

Antonas, K. N., Fraser, J. R. E., and Muirden, K. D. (1973). Distribution of biologically labelled radioactive hyaluronic acid injected into joints. Annals of the Rheumatic Diseases, 32, 103-111.

Barka, T., and Anderson, P. J. (1962). Acid phosphatase techniques using hexazonium pararosanilin as coupler. Journal of Histochemistry and Cytochemistry, 10, 670.

Baxter, E., Fraser, J. R. E., and Harris, G. S. (1973). Fractionation and recovery of secretions of synovial cells synthesized in culture with radioactive precursors. Annals of the Rheumatic Diseases, 32, 35-40.

Bollet, A. J., Bonner, W. M., Jr., and Nance, J. L. (1963). The presence of hyaluronidase in various mammalian tissues Journal of Biological Chemistry, 238, 3522-3527.

Clarris, B. J., and Fraser, J. R. E. (1967). The effects of homologous and heterologous whole serum upon multiplication of recently-isolated human synovial cells in culture Australian Journal of Experimental Biology and Medical Science, 45, 549-560.

Clarris, B. J., and Fraser, J. R. E. (1968). Relationship between chromosomal changes and alterations in the behaviour of a strain of human synovial cells during its life history in vitro. Annals of the Rheumatic Diseases, 27, 597-603.

Dingle, J. T. (1975). The secretion of enzymes into the pericellular environment. Philosophical Transactions of the Royal Society of London, Series B, 271, 315-324.

Dingle, J. T., and Barrett, A. J. (1969). Some special methods for the investigation of the lysosomal system. Lysosomes in Biology and Pathology, Vol. 2, p. 557. Ed. by J. T. Dingle and H. B. Fell. North-Holland, Amsterdam.

Dingle, J. T., Fell, H. B., and Glauert, A. H. (1969). Lysosomal and other biochemical effects of sugar endocytosis in embryonic skeletal tissues in organ culture. Journal of Cell Science, 4, 139-154.

Flodin, P., Gregory, J. D., and Roden, L. (1964). Separation of acidic oligosaccharides by gel filtration. Analytical Biochemistry, 8, 424-433.

Fraser, J. R. E., and McCall, J. R. (1965). Culture of synovial cells in vitro. Annals of the Rheumatic Diseases, 24, 351-359

Fraser, J. R. E., Khean, W. F., and Maritz, J. S. (1972). Viscous interactions of hyaluronic acid with some proteins and neutral saccharides. Annals of the Rheumatic Diseases, $31,513-520$.
Glauert, A. M., Fell, H. B., and Dingle, J. T. (1969). Effectof sucrose on cellular fine structure. Journal of Cell Sciences. 105-131.

Goldberg, A. F., and Barka, T. (1962). Acid phosphat activity in human blood cells. Nature, 195, 297.

Harris, G. S., and Fraser, J. R. E. (1969). Extractions ånd measurement of glycosaminoglycans in serum and culture medium: a system with the use of an aliphafic quaternary ammonium salt. Journal of Laboratory Clinical Medicine, 74, 527-535.

Kochhar, D. M., Dingle, J. T., and Lucy, J. A. (1968). Tीhe effects of vitamin A (Retinol) on cell growth and incorporation of labelled glucosamine and proline by mouse fibroblasts in culture. Experimental Cell Research, 35, 594 601.

Le Marshall, J., Fraser, J. R. E., and Muirden, K. D. (1973). Induction of lysosomal activity in isolated synovial ce the response to neutral sugars. Australian and New Zealaged Journal of Medicine, 3, 533-534.

Meyer, K. (1947). The biological significance of hyaluronic acid and hyaluronidase. Physiological Reviews, 27, 335-3 $\overline{8}$.

Muirden, K. D. (1972). Lysosomal enzymes in synovial membrane in rheumatoid arthritis: relationship to joint damage. Annals of the Rheumatic Diseases, 31, 265-271. -

Munro, T. R., Daniel, M. R., and Dingle, J. T. (19). Lysosomes in Chinese hamster fibroblasts in cultu Experimental Cell Research, 35, 515-530.

Nyberg, E., and Dingle, J. T. (1970). Endocytosis of sucrese and other sugars by cells in culture. Experimental cejl Research, 63, 43-52.

Page Thomas, D. P. (1969). Lysosomal enzymes in expeु1mental and rheumatoid arthritis. Lysosomes in Biology Pathology, Vol. 2, p. 87. Ed. by J. T. Dingle and H. B. Fej1. North-Holland, Amsterdam.

Pearse, A. G. E. (1968). Histochemistry, Theoretical of Applied, 3rd ed., Vol. 1, p. 559. Churchill, London.

Reissig, J. L., Strominger, J. L., and Leloir, L. R. (1959). A modified colorimetric method for the estimation $\mathrm{G}$ $\mathrm{N}$-acetylamino sugars. Journal of Biological Chemistry, 217, 959-966.

Scott, J. E. (1960). Aliphatic ammonium salts in the assaypof acidic polysaccharides from tissues. Methods in Biochemical Analysis, p. 145. Ed. by D. Glick. Intersciepe Publishers, New York.

Weissman, G., Dukor, P., and Zurier, R. B. (1971). Effect cyclic AMP on release of lysosomal enzymes from phagocytes. Nature New Biology, 231, 131-135.

Werb, Z., and Reynolds, J. J. (1974). Stimulation by endoey. tosis of the secretion of collagenase and neutral proteinese from rabbit synovial fibroblasts. Journal of Experimental Medicine, 140, 1482-1497. 